\title{
Cytokeratin-5 Staining Method
}

National Cancer Institute

\section{Source}

National Cancer Institute. Cytokeratin-5 Staining Method. NCI Thesaurus. Code C122859.

An immunohistochemical technique used to detect the presence of cytokeratin-5 in a tissue sample. 